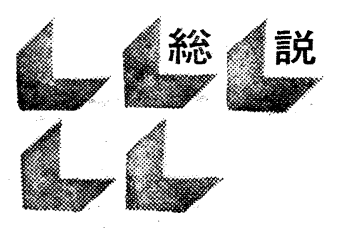

\section{ま えがき}

AN-FO 爆薬とはいらまでもなくAmmonium Nitrate-Fuel Oil Blasting Agents (or Mixture) の頭 文字 AN-FO をとつたわけであるが，これを爆薬 (Explosive) として取扱らか, 混合物 (Mixture) として取 扱らか，すふわちこの爆薬の法的取扱いについては現在 わが国でも問題になつているので，ここでは特にふれな いが，諸外国においても大体爆薬として取扱つているよ らであるし，わが国においても昭和34年7月21日付の通 産省軽工業局の通達 716 号によると火薬類取締法による 硝安爆薬の範ちゆうに属するものとされているので, こ こでは $\mathrm{AN}-\mathrm{FO}$ 爆薬といら言葉を用いて解説することと した。

\section{AN-FO 爆薬の歴史と使用状況}

本誌 2 月号に揭載されている採鉱関係の傾向や本年 1 月に開催された座談会の記事をみても, 最近釯山界でこ の爆薬の使用が問題になつていることがわかる。

一般に AN-FO爆薬と呼将れるもの恓格が比較的安 、肥料用硝安 $(28$ 円 $/ \mathrm{kg}$ ) や工業用硝安 (34円 $/ \mathrm{kg}$ ) に燃料 としてコールタール, アントラセン油, 軽油等硝安と混 合し易い燃料油を混ぜたもので, 前記のように爆薬の取 披は受けているが，従来の爆薬とはおおよそ簧なるもの である。

AN-FO 爆薬はその使用法加ら分類すると, 発破孔に 硝安と燃料油とを現場なり，工場なりで混合し，これを 装填器（加圧型とエゼクタ一型の 2 種あり）を用いて直 接装填するものと，もう一つ硝安と燃料油とを混ぜた むのを薬包に入れて通常の爆薬と同様に装填するものと の2種類がある。しかし，これを起爆せしむるに良せ般 にダイナマイト類をプライマーとして用いることが必要 である。これ酸化剂としての硝安が鈍感であるからで これを細粒として表面積を増加させる鋭感とするなどの 方法も考えられているが，これにも限度があるので最近 は日本化薬のA-3爆薬のように界面活性剂老用いて爆発 性をよくし，プライマーを用いなくても雷管で起爆でき るものもできている。

硝安はもともと1800年代から爆薬の原料として用いら れてきたが，これは硝安にニトログリセリンのような鋭

\footnotetext{
* 工博 早稲由六学敨嗳 資源工学科
}

UDC 662.24

\section{爆 薬}

正会員田中正男*
感剤を混ぜて用いたもので，AN-FO 爆薬のように燃粒 油と混合して用いられる上らになつたのは1955年できだ 比較的新らしい。

$\mathrm{AN}-\mathrm{FO}$ 爆薬は最初肥料用多孔質プリルの粗粒の硝安 を用いたので臨界薬径が大きく露天掘の大口径発破にし か用いられなかつたが，最近微精あるいは粉状の硝安を 用いたり，前述のような有機性の活性剤を用いて爆発性 能を向上させ小口径の発破にも用いられるよ.うになつ た。また携帯用の小型混合機や装填器も考案されて $\mathrm{AN}$ FOは坑内にも使われつつある。

最近のアメリカ合衆国の使用状況をみると1960年には 全使用量55万 $\mathrm{t}$ の 5 520 万 $\mathrm{t}(36 \%)$ が $\mathrm{AN}-\mathrm{FO}$ 爆薬で, このうち5\% は坑内で消費されている。1961年にはこの 值が更に $60 \%$ に昇し，ダイナマイト工場の閉鎖される ものもできてきたような状態である。一方，欧州諸国で は米国と比較すれば多くは用いられていないが爆薬方面 で忖先進国であるウェーデンでも，この使用に関する研 究が進められ, 坑内における使用も含めて全使用量の7 \%が AN-FOで占められている。ドイッで法法規によつ て真填式が禁じらているので，実用にけ用いられてい ないようである。イギリス，ベルギーでも一部坑外用に 用いられている程度で，アメリカにおける使用状況とは 問題にならない。このように欧州と米国では使用状況が かなり異なるよらにみえる。

わが国の使用状況は現段階では取締関係法規の関係か ら試験使用の籍团を出ていない。しかし，自由化に対抗 するためにはこのような新技術をどしどし導入すべきで 考えられる危険は排除する工夫をして一時も早く鉱山の 現場に普及させるべきであろら。

\section{AN-FO 爆薬と他の爆薬の比較 ならびにその特徵}

$\mathrm{AN}-\mathrm{FO}$ 爆薬と従来の爆薬の比較を爆発性能と価格の 両面から比較し，その特徵について述心゙る。

\section{$2 \cdot 1$ 性能面からみた比較}

爆発と伝播の両方の感度，すなわち爆発させるために 洁何本のプライマーを要するか，また，殉爆させるため に瀶界薬径がどの位になるか？などをしら心゙る必要 がある。

これら, 感度, 殉爆性等をしらべる力法は種々あるが AN-FO 爆薬に対して試験したものはアメリカにおいて 

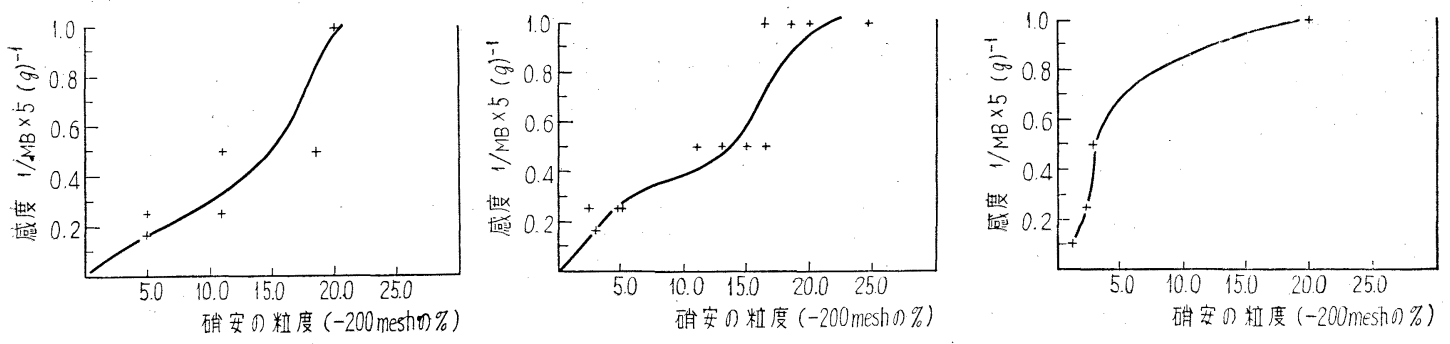

(左上り $1 \sim 3$ 図)

第 1 ３図 硝安の粒と感度の関係（硝安の粒度 -200 mesh \%)

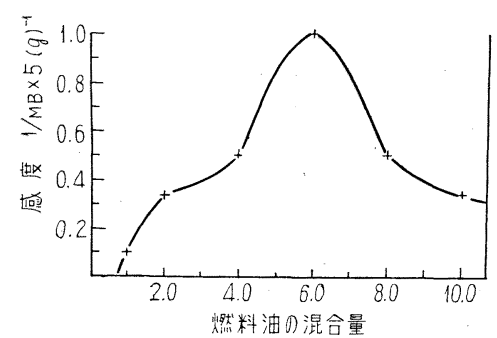

第 4. 図 燃料油の混合量と感度の関係

はGrubb 氏の実験1)，わが国に㧍いては下村教授の実 験 ${ }^{2)}$ がある。

Grubb 氏の実験において感度を示すのにAN-FO 爆 薬を起爆せしむるに必要なペントリットの量で示し，硝 安の粒度と感度の関係について燃料として液体燃料（デ ィーゼル油 2 号) を使用した場合と固形燃料を使用した 場合について述心゙ているが，粒度は細かいものほど感度 が高くー200mesh が 20\% 以上あることがよいとしてい る。また多孔質プリルを使う場合には孔中に然料が滲透 するため少々粗くても多孔質でないものの細かいものに 相当する効果があると述べている。これらの実駺におい

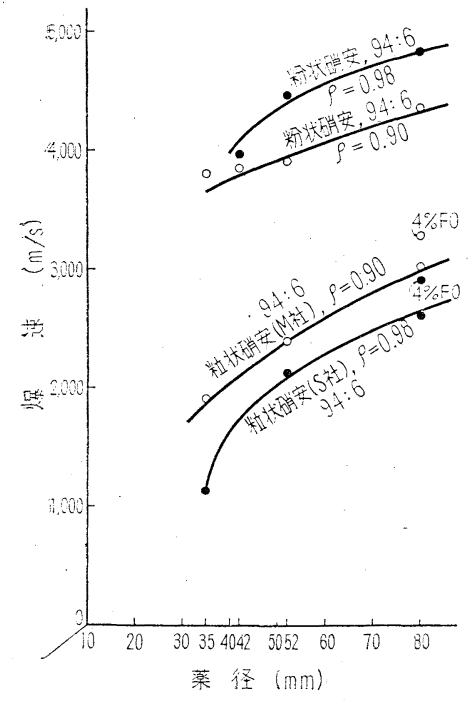

第 5 図

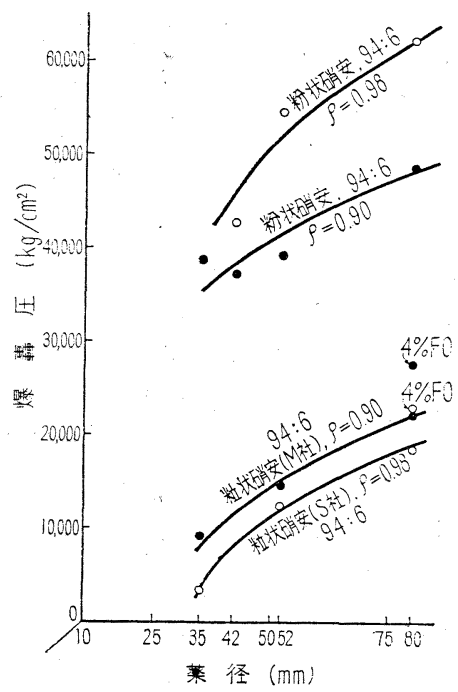

第 6 図
ては硝安と然料油の混合比を94.5:5.5(液体燃料の場合) 〜94: 6(固形燃料の場合) 92. $5: 3.0: 4.5$ (硝安 : デニ トロトルエン(D.N.T.) : 固形燃料の 3 者混合)として行 なつている。この混合率も感度ならで爆力に影響があ りディーゼル油 2 号の場合法 $6 \%$ 混ぜた場合最大の効果 を発揮するとしている。さらに硝安の代りに硝酸ナトリ ウムを用いても効果がないとしている(第1４眘参照)。

下村教授は爆速試験を行ならここによつて比較を行な つている。すなわち，原材料としての硝安は一般に市販 されている普通品を用いGrubb 氏の実験の上うに多孔 質のプリルは用いていない。燃料油に注軽油 3 号 (U.S. A.のディーゼル油 2 号に相当するもの) を用、混合比率 はGrubb 氏の例にならつて94:6 (硝安：然料油) を原 則としている。

硝安と燃料油の混合住磁性乳鉢で行なつており，プラ イマーとしで3号竹ダイナマイトを用いて起爆させてい る。実験結果は次のように要約される。すなわち,

(1) 薬径, 硝安の粒度, 装填比重等と爆速の関係に ついて㴡径が増大するとともに爆速は放物線状に増大 する(第 5 図参照)。硝安の粒度については, 粉状と粒状 の比較しか行なつていないが粉状の方 が比較的完全に爆轟している。装垻比 重については高いと爆速む速くなり薬 径がある程度以上大になれば，爆速は ほぼ装继比重に比例するといつて差支 えない。

（口）薬径, 硝安の粒度等之爆轟圧 の関係については爆轟压は爆速の自乗 と装枨比重の櫝に比例するが日野氏の 計算式を用いた爆輬圧と薬径の関係は 第 6 困に示すように第 5 図の爆速の場 合と似ている。すなわち, 粉状硝安の 場合装塡比重 0.90 で 4 5 万気圧, 装 填比重が 0.98 になれば 4 亿気圧で装 填比重が相当重要な役割を占め,この 点からも発破孔にAN-FOを真填して 装填比重をあげた方がよいことがわか 
る。

（ハ）薬長と爆速との関係については，粉状硝安の場 合には薬長の増大に上る爆速低下法あまりみられないが 粒状硝安の場合には距離の増大に伴なつて爆速が低下し ている。この傾向は薬径が小さくなるほど強まるとして いる。この点から臨界薬径忙 $25 \mathrm{~mm}$ 位と考えら礼るが現 在用いたよらな原材料なら $80 \mathrm{~mm}$ 程度と考えられる。

（二）ブースタの量については $\mathrm{AN}-\mathrm{FO}$ 爆薬の感度に よつて支配され，粉状硝安の場合法 $\mathrm{AN}-\mathrm{FO}$ 爆薬の $10 \%$ 粒状硝安の場合は $20 \%$ としている。

また $\mathrm{AN}-\mathrm{FO}$ 爆薬に抒いて以燃料油が硝安中に渗透す ることが必要であるが，このことについても実験してい る。

さらに下村教授法 $\mathrm{AN}-\mathrm{FO}$ 爆薬の鉱山にお括る実用化 を目的として石灰石の露天掘 2 鉱山(羽鶴, 勝举), 金属 鈗山の坑内掘 4 鉱山（神岡, 河山, 細倉, 赤金)において試 験研究を実施した ${ }^{3)}$ 。この試験研究においては基礎研究 としての爆速試験, 現場における適用性を調心゙るための 発破試験ならびに坑内の場合汸跡ガスの検定等が行なわ れたが，以下各項目別にその大要を述べることとする。

\section{I. 爆速試験}

（イ） $\mathrm{AN}-\mathrm{FO}$ 爆薬の爆速は薬径の増大に伴なって速 くなり(第 5 図参照),薬径が $50 \mathrm{~mm}$ 以上になると, 爆速は $4,500 \mathrm{~m} / \mathrm{sec}$ 以上の值を示す。一方薬径を小さくした場合 は21.6mmで約 $2,800 \mathrm{~m} / \mathrm{sec} の$ 爆速を示し，16mmでも完 爆したすのがあるので, 臨界薬径は $16 \mathrm{~mm}$ 程度とみてよ いだろう。したがつて, 孔径の点では従来の発破と変り なく使用できる。な抢徉来の他の爆薬と比較する意味で 粉状硝安で薬径 $35 \mathrm{~mm}$ の場合の爆速をみると 4 孔の平均 で約 $4,000 \mathrm{~m} / \mathrm{sec}$ で, 最近改良されたAnoloder*で装䱋し た場合約 $3,500 \mathrm{~m} / \mathrm{sec}$ を示している。

この值交 JIS規格の萩ダイナマイト $(4,000 \mathrm{~m} / \mathrm{sec}$ 以上 $)$ 硝安ダイナマイト ( $3,000 \mathrm{~m} / \mathrm{sec}$ 以上) に苏たる。

(口) AN-FO 爆薬のプライマーとしては爆速の高い ものほどよいと云われ，一般には新桐，桐 3 号ダイナマ イトが使わ机る。その量法 $\mathrm{AN}-\mathrm{FO}$ 爆薬の薬径が $28 \mathrm{~mm}$ 程度以上なら使用する $\mathrm{AN}-\mathrm{FO}$ 爆薬の量の $3 \sim 4 \%$ で 上小。

中間また忏底にブースタとしてダイナマイトを插入 して子特に AN-FO 爆薬の爆速を高める効果は顕著に現 われない。

AN-FO 爆薬法開放状態に执いては勿論のこと，たと

* Anoloder : エゼクター型装填機の一種で米国の A.C.C 製, 容器は アルミ製で251bの AN-FO を入れ装填能力は内径 $11 / 8$ ", 長さ $14^{\prime} の$ ポリエチレンホースを用いて $4.9 \mathrm{lb} / \mathrm{min}$, 片手でリモートコントロ 一ルバルブを握り，片手で装填六一スを持つて，1 人で操作がでさ る。必要なら折畳みの脚で装填場所の㦿に固定でき, その位置で孔 込めをして重量が減少したら装填機を眉にかけて装填を続けること もできる(第 8 図参照)。
え密閉状態においても雷管単独で起爆させることははな はだ困難である。

（八）硝安と然料油の混合については現場で使用直前 に混和することがよく，火薬工場やその他指定された場 所で混合して輸送する時は時間経過のために生じた油の 分離，浸出があるため現場で再䚓汼（再調整）をしなけ ればならぬので硝安と燃料油の混合恃鉱山の現場で行な つた方がよい。

（二）硝安メ一カの努力によってアメリカで用いられ ているよらな多孔質の粒状硝安が開発されてきたので爆 速は粉状硝安に近くなつた。一般に粒状硝安は粉状硝安 より取报上有利で，とくに固結固化することが少なく貯 蔵上の問題も少ないので, できれば爆発性能のよい粒状 硝安ができることが望ましい。

\section{II. 発破試験}

A. 露天採掘：露天掘に扮け当発破試験怯羽鶴(杤木) と勝峯(西多摩)の両鉱山で行なわれ, 羽鶴に扔いては火 薬工場で混合包装し，遠距離を輸送してきたものをその まま使用したため油が分離浸出して含油量が理諭含油量 に比して不足気味の上, 含油率す著しく不均一であつた が従来の爆薬と同程度の性能を示じた。したがつて現場 混合によつて正常なものが供給されれば一厤発破効果が 上ることが期待される。

勝峑鉱山に扔いては小口径発破の試験を行なつたが, 上記のような欠点をさけるため現場において再混合して 油の均一化を計つたので薬径 $27 \mathrm{~mm}$, 孔長 $4 \mathrm{~m}$ の発破孔 においてる確実に点爆され, 従来の爆薬に比して劣らな い発破性能を示した。

B. 坑内採掘：神岡鎕山に打いて法下向長孔採掘切羽 において試験が行なわれ，発破孔の直径は $40 \mathrm{~mm}$ ，長さ は $14 \mathrm{~m}$ で最小抵抗線 $1.5 \mathrm{~m}$, 孔間隔は $2.0 \mathrm{~m}$ と従来の発破 に比して若干大きくとつたが（従来の発破では最小抵抗 線 $1.3 \mathrm{~m}$ ，孔間隔 $1.8 \mathrm{~m}$ ) 上く発破することができ，粗鉱

$\mathrm{t}$ 当たり $25 \%$ の薬量の減少に成功した。

赤金鉣山においては水平臯型長孔採掘切羽において試: 䍄が行われ, 発破孔の直径は $39 \mathrm{~mm}$, 孔長 $9 \sim 14 \mathrm{~m}$, 最 小抵抗線 $1.2 \mathrm{~m}$, 孔底における孔間隔 $2 \mathrm{~m}$ といつた発破 設計で水平上り約 $20^{\circ}$ 上向きに同一平面内にあるように 穿孔されたすのに圧気装䱋機を用いて装䱋し，プライマ 一は新桐ダイナマイトを口元において発破を行なつた が，これも成功している。

河山鉱山においてはベンチングの半長孔発破の試娩を 行ない，発破孔の直径 $34 \mathrm{~mm}$ ，長さ $3 \mathrm{~m}$ で従来の爆薬之 同量の AN-FO 爆薬を用い従来のものより好結果を得て いる。

細倉鉱山ではストーパによる上向穿孔箇所で試験を実 施したが，Anoloder 装塡機を用いて装填した結果こぼ 
れ落ちることもなく成功裡に終つた。

次追切, 坑道掘進に打沙発破にも忘用したがす心゙ て好結果を示している。

\section{$2 \cdot 2$ 価格からみた比較}

AN-FO 爆薬のコストは山元混合の場合には，40 50 円 $/ \mathrm{kg}$ で従来の爆薬の約 $1 / 5$ である。

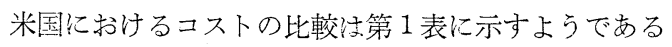
が第 2 表に示した発破孔 $1 \mathrm{ft}$ 当たりの量と合せ考えると， $\mathrm{AN}-\mathrm{FO}$ 爆薬が如何に安くつくかわかる。

第 1 表 米国に㧍ける各種爆薬の価格比較

\begin{tabular}{lcc}
\hline Nitramon & $100 \mathrm{lb}$. & $\$ 17.80$ \\
Nitrox & $\prime \prime$ & $\$ 19.45$ \\
$60 \%$ Geratine Dynamite & $\prime \prime$ & $\$ 24.85$ \\
$60 \%$ Ammonium Nitrate Explosive & $\prime \prime$ & $\$ 19.25$ \\
Slurry Explosive (市骐) & " & $\$ 17.36$ \\
Slurry Explosive (自家製造) & " & $\$ 7.70$ \\
AN-FO Explosive (94:6) (自家製造) & $\$ 5.00$ \\
\hline
\end{tabular}

第 2 表 径 $10^{\prime \prime}$ の発破孔 $1^{\prime}$ 当たりの爆薬使用量

\begin{tabular}{llll}
\hline Nitramon & $8^{\prime \prime}$ 缶 & $32.5 \mathrm{lb}$. \\
Nitrox & $8^{\prime \prime}$ 缶 & $41.75 \mathrm{lb}$. \\
Slurry & & $47.5 \mathrm{lb}$. \\
AN-FO & $27.25 \mathrm{lb}$. \\
\hline
\end{tabular}

\section{$2 \cdot 3 \mathrm{AN}-\mathrm{FO}$ 爆薬の特徵}

以上他の爆薬との比較検討を行なつたが, これらから AN-FO 爆薬の特徴を示すと次のようになる。

（1）個々のものとしては左程危険なものでない肥料 用硝安, あるいは工業用硝安と燃料油が原料であるので ニトログリセリンのような爆発性の鋭感剤が入つている 從来の爆薬と比較し、て取扱いが極めて安全である。

(2) 前述のように価格が格段汇安い。

（3）ダイナマイトなどの強力な爆薬がなければ, 雷 管のみでは起爆できないくらい鈍感であるが，真填した 発破孔内で一旦起爆すれば従来の薬包爆薬以上の威力を 発揮し, 跡ガスも従来のものよりむしろよく, 坑内お上 び坑外のあらゆる発破に対して有利に適用される。

（4）現場で硝安と燃料油を混合して所要の量を作れ ばよいので, 従来のような火薬庫を $\mathrm{AN}-\mathrm{FO}$ 爆薬のため 飞設ける必要はない。（前述のように $\mathrm{AN}-\mathrm{FO}$ 爆薬のみ では霓管による起爆が出来ないので，ダイナマイトをプ ライマーとして使うので, これらに対する設備は必要で 㐫る)

（5）硝安と燃料油の混合には特別の施設を必要とせ ず安全, 容易に行なうことができる。

（6）方一不発残留薬を生じても，その処理が注水な どによつて容易にできる。

（7）雷管で起爆できぬくらい鈍感であるので, 残留 薬にビットが触れることがあつても爆発の心配はまずな
以。

（8）他の爆薬のように変質したり，涷結したりする 心配がない。

\section{AN-FO 爆薬の問題点}

$\mathrm{AN}-\mathrm{FO}$ 爆薬はすでに述べてきたように従来の爆薬と は著しく巽なつたいたつて簡単に，しかも安全に製造が でき, 発破効果も従来の爆薬と比較して遥色のないもの である。

しかし，この爆薬に法以下に示すようないくつかの問 題点がある。以下，これらの問題点を(1)原材料として の硝安の性状 (2) AN-FO 爆薬を現場で使う場合の諸 問題 (3) 保安の3つに分けて検討をすすめることに する。

\section{$3 \cdot 1$ 原材料としての硝安の性状}

米国での $\mathrm{AN}-\mathrm{FO}$ 爆莫の傎用が近年急激五ええてきた のは，(1) 軍放出のプリル硝安製造装置を用いてプリル 硝安が非常に安く, 普通硝安の価格の $1 \frac{1}{3}$ でできること, （2）プリル硝安の特徴として低比重 (0.8) で油を吸い易 く, 且つ, 圧気装填すれば密装填ができること，(3) 燃 料油の発達により軽油（ケロシンに近いもの）が量産で きるようになつたこと（5）火薬類でないかからどこで もコンクリートミキサーのようなもので混和できるこ と，等があげられているが，わが函においてはこれらの 事情が大分異なる。すなわちまず第 1 亿わが国ではプリ ル硝安の製造はまだその途上にあつて実用には供されて いない。わが国の肥粒用; 工業用硝安は前述の上うに粉 状と粒状のものが多いが, 粉状のものでも第 3 表に示す ようにそそう細かくなくむしろ微粒といつた方がよ く, 比重も米国のものより高いと考えられる。

第 3 表 硝安の粒度分布 (下村教授汇よる)

\begin{tabular}{|c|c|c|c|c|c|}
\hline \multicolumn{2}{|c|}{ 粉 状硝 安( $\mathrm{S}$ 社) } & & 粒 & 硝 & 安 \\
\hline サイズ(mesh) & 重量 \% & サイン & "(mesh) & $\mathrm{S}^{\text {重 }}$ & $\frac{\text { 量 \% }}{\text { I M 社 }}$ \\
\hline 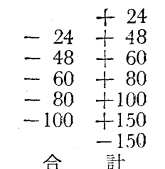 & $\begin{array}{r}0.2 \\
11.8 \\
12.0 \\
20.0 \\
24.0 \\
20.0 \\
12.0 \\
100\end{array}$ & -8 & $\begin{array}{l}+8 \\
+16 \\
-16\end{array}$ & $\begin{array}{r}1 \\
96 \\
3\end{array}$ & $\begin{array}{r}0 \\
98 \\
2\end{array}$ \\
\hline
\end{tabular}

このように原材料の硝安が多少の亀裂や孔隙を持つて いるとしても大体緻密で結晶質に近いすのが多いため米 国で用いられている多孔質プリルと異なり燃料油の吸収 が悪く,そのため反応も完全に行なわれず爆速も期待し たほどはでない。そして燃料油の混合量が $6 \%$ で法見掛 上燃料油が過剩となり，むしろ燃料油の混合量が $4 \%$ の 場合の方がよい結果を得ている。

現在硝安メ一カの努力によつて多孔質の粒状硝安がわ 


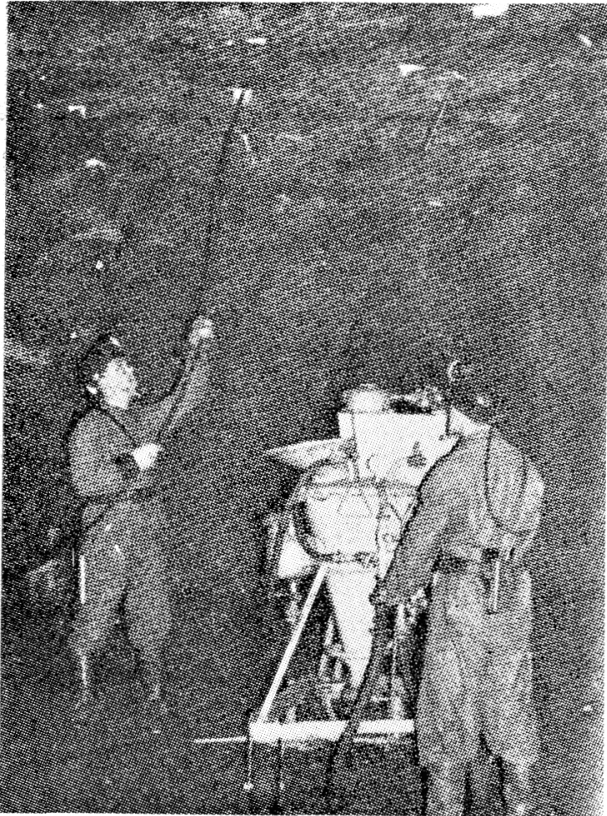

（a）切羽における使用状況

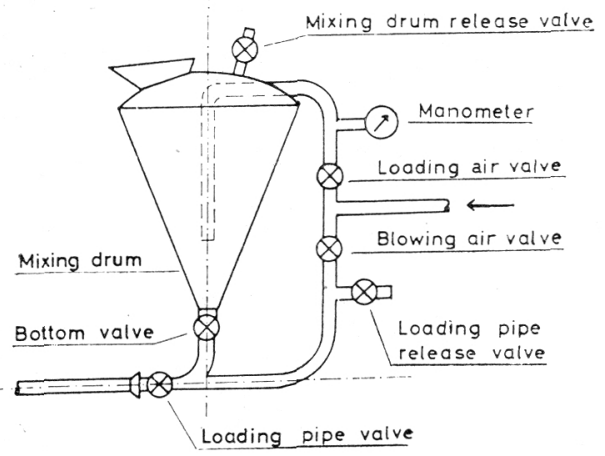

(b) 装置の略図

第7図 混合装塂機

が国でも開発さ礼つつあるので，粉状硝安に止心゙て取扱 が便利で,とくに固結固化することが少なく,貯蔵上の問 題も少ない。粒状硝安が一般の娕用经供され，爆速の速 、爆発性能り上い $\mathrm{AN}-\mathrm{FO}$ 爆薬の出現が期待されている

\section{$3 \cdot 2 \mathrm{AN}-\mathbf{F O}$ 爆薬を現場 (切羽)で使う場合の諸問題}

AN-FO 爆薬恃すで何回も述べたよう硝安と燃料 油を一定の割合で均一に混合するだけのことで歧るが， この製造を行なう莂所から次の 3 つ分计られる。すな わち, (1)硝安と燃料油を現場において混ぜる。これには

* スウニーデン製混合装故機の一種で， 2 人で操作する。即ち 1 人は

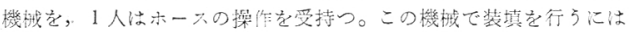

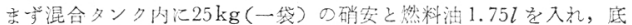
についているパルブを開いて压父を間タッ的にブローパイプを操作 して入れ混合する。2〜3分で湿合が完了するので、ローデイング・ パイプを開いて発破孔汇装填寸る。装㙋圧は2 $3 \mathrm{~kg}$ である(第7

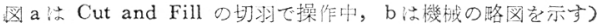

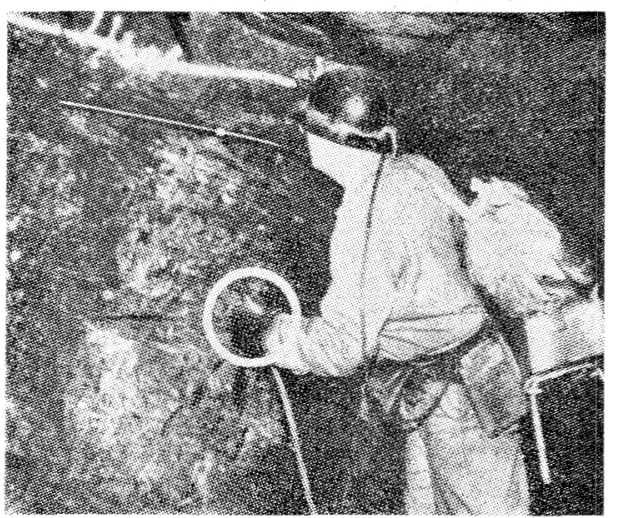

第 8 図

普通第7図汇示寸ような混合装填機”や，二れ携带型 にした第8㘠に示すAnoloder が用いられる。前者法主 として露天掘やサブレベルストーピングに，後者䧄せま い採掘切羽や坑道掘進切羽等汇用いられる。(2) 現場か ら離れた中央混合プラントで一括して混合を行ないここ れを切羽に運搬して装塡機老用いたり，下向きの孔なら 流し込んで装填する。(3) 従来の爆薬のように中央製造 所なり火薬会社で袋詰にして，こ机を切羽で装埧する。

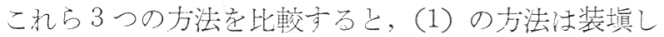
上らとする現場で混合，装陉を同時に行なつてしまうの で切羽に侉険物を運んでくるということがない。すなわ ち AN-FO爆薬となつたもの輸送したり，貯蔵する上 り危除性が少ない。

また，燃料油分が揮発また法浸出したりして分離する こともなく。包装上の問題もないので，経費も安くつく ので，でき枕ばこの方法が望ましい。しかし，現在はこ れは火薬の製造となるので火薬製造の許可を得な゙扎ば できない。AN-FO爆薬の製造は鋭感剤を入れる硝安爆 薬やカーリット，ダイナマイト等の製造と異なつて極內 て単純，簡単，かつ安全な作業であるので従来の爆薬製 造工場の上うな設借规準注不必要で，も5少し簡単な晥 則の下に許可さる心゙きであるう。

(2) の方法の長所は中央混合プラントで一括して混合 するので混合状況の管理もうまくゆくし，切羽で洁装填 のみで上いので下げ孔に対しては流し込みも可能である し装堫機も（1）のものに比較して簡単なものですむ。し かし，このプラントの距離が遠い場合は現場で再混合し なければなら齐ので近くのもののみを一括して混合する とよい。(1)，(2)の方法とも压気を用いて装垻するので 装境密度を上げることがだき，したがつて発破効果を向 上できるといら利点がある。

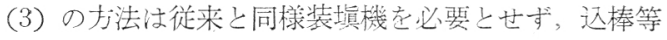
でできるという点で小規模の鉱山注便利で西るう。乙 かし燃料油の分離等汇注意する必要が击る。 
$\mathrm{AN}-\mathrm{FO}$ 爆薬の装塡には前に述べたように装填機を用 いて行ならのが普通であるが，この場合，パイプ内で $\mathrm{AN}-\mathrm{FO}$ 爆薬がつまることがある。この場合はブローパ イプを開いてやれば圧気圧で除去できる（装填用の圧力 は通常 $2 \mathrm{~kg} / \mathrm{cm}^{2}$ に対しブロー圧は $\left.8 \mathrm{~kg} / \mathrm{cm}^{2}\right)$, また混 命タンク内で棚をつることがあるが，これ㥙混合タンク の裏張りをステンレスにしたりすることによつて，除去 できるので大した問題ではない。装填の際の帯電の問題 についてけ次項（保安）で述べ。

AN-FO 爆薬は水孔に注用いられないといわれるが， 発破孔に合つたプラスチック製の袋を用意すればこの問 題き解決できる。

\section{$3 \cdot 3$ 保 安}

保安上の問題としては，(1) 製造中あるいは運搬中,

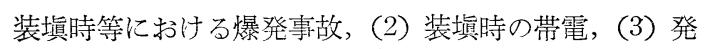
破跡ガス，(4) 不発の処理，(5) 貯蔵等の諸問題があ る。

（1）製造中, あるいは運搬中, 装填時等における爆発

事故肥料用硝安や工業用硝安そのものは, 火薬類で はないが取扱いを注意しないと意外な事故を起すことが ある。火薬類の専門家の意見によると一度溶融した硝安 が泠却凝固する過程沉捻いて比重が低下して膨らむ状態 があるが，この状態の硝安は 6 号電気、雷管で完爆できる といら。また，硝安に上る事故はかなり多く，古くは 1921年にOppau で起きた爆発事故があり,これ法 4,500 七の硫安と硝安の混合物 $(2: 1)$ が爆発したもので 509 名 が死亡した大事故である。さらに1944年には Millanの 工場で爆発があり，硝安原液の蒸発槽に油が入つたのが 原因といわれる。この事故では 4 名の死者を出している が硝安に油が入ると爆発性を増すことを示しているよう である。最近の例では本年 1 月にフィンランドの $\mathrm{Ou} \mathrm{Lu}$ の硝安製造工場で爆発が起り10名の死者とほぼ同数の負 傷者を出している。これらの事故は何れも硝安の製造過 程に扔いて起きた事故のようで，肥料用や工業用等の硝 安の運搬中とか貯蔵中に起きたものでないので取扱いに 注意する事壮勿論大切であるが，一般の火薬類のような 危険なものではなく，十分注意すれば避けられるものと 考えられる。

$\mathrm{AN}-\mathrm{FO}$ 爆薬の爆発事故はこの爆薬が使われ始めてま だ日が浅いので数は少ないが，1つは米国のバージニア 州ノルトンで起きた事故で，1961年12月27日同地の工場 でコンクリートミキサーで混和中の50 t の混合品ならび に末混合品が爆発を起している。この原因は明らかにさ れていないが，燃料油が配合されているので火が付き易 く，燃焼より火災，量と状態によつて爆発にまで及んだ と解釈されている。今 1 つ1961年1月30日にジェファ ーソンアイランドで起つた事故で, 現場で AN-FO爆薬
の装填中に爆発事故を起したものであるが，この事故の 原因は压気装填機を用いて装塡中摩擦に上つて坐じた静 電気が原因と考えられる。㓜論, この他に迷走電流や電 気施設の漏電といらことも考えられるが，この場合には， この静電気が電気雷管を起爆したものと考兄られる。

（2）装填時の帯電 AN-FO 爆薬をパイプを通し て発破孔に装填するときに発生する静電気は上記事故 が示すように危険であるがアメリカの鉱山局の報告に よると $1,000 \sim 8,000 \mathrm{~V}$ がチャージされることがあると いわれ, この量はプリルの流動速度, 大気の温度, 湿 度, 壁面の伝導度によつて変化すると云われている。こ の静電気を逃がすにはステンレス容器による混合と半伝 導性プラスチックホースの使用が保安上よいとされてい る。忠た, 装填器からアースをとること, パイプやケー ブル等電流を発生する装置から装墳機を遠ざけておくこ とが必要である。一方,メーーカーの方でも組成の上から 静電気带電が最小となるようなすのが研究されており， アメリカの C.I.L. では Amex. IIのような製品を出して いる。

（3）発破の跡ガス 下村教授による実測結果によ ると ${ }^{3)}$ 採掘切羽にお 跡ガスは極めて稀薄で, $\mathrm{CO}$, $\mathrm{NO}_{2}$ および $\mathrm{CO}_{2}$ はいずれも許容濃度以下のガス状態 であり,したがつて通常の採掘切羽で通常規模の発破を 行なら場合には $\mathrm{AN}-\mathrm{FO}$ 爆薬を使用するための特別の通 気対策を必要としないとしている。

米国に掠いては，一応通気を行なつた方がよいとして いるが，坑夫はニトログリセリンによる頭痛もなく，跡 ガスも刺激的でないので, むしろ，この発破の方が上い としている。

いずれの場合においても硝安と油の正しい混合が行な われ，十分な量のプライマーを使用すれば有害な跡ガス の発生は最小になる。

なお，下村教授がほとんど通気のとれていない盲坑道 の切羽で測定した結果によれば AN-FO 爆薬 $1 \mathrm{~kg}$ 当た りの発生ガス量唗従来の爆薬のそれと大差ない。すなわ ち従来の爆薬では $\mathrm{CO}$ が $2.6 \sim 75.0 \mathrm{ppm} / \mathrm{kg}, \mathrm{NO}_{2}$ は $0.08 \sim 6.6 \mathrm{p} \mathrm{pm} / \mathrm{kg}, \mathrm{CO}_{2}$ は $164 \sim 810 \mathrm{ppm} / \mathrm{kg}$ に対し, $\mathrm{AN}-\mathrm{FO}$ 爆薬の場合は $\mathrm{CO} か ゙ 1.1 \sim 5.45 \mathrm{ppm} / \mathrm{kg}, \mathrm{NO}_{2}$ は $0 \sim 7.2 \mathrm{ppm} / \mathrm{kg}, \mathrm{CO}_{2}$ は. $22 \sim 614 \mathrm{ppm} / \mathrm{kg}$ であつ た。

また，輸送中や貯蔵中に油が分離して不均一な状態に なると発破跡ガス中の $\mathrm{CO}, \mathrm{NO}_{2}$ ガスのいずれも増大す る傾向があるので AN-FO 爆薬注混和後直ちに使用され ることが望屯しい。

（4）不発の処理 AN-FO 爆薬は一般には発破孔 に直垻され，爆速の低下も少なく，殉爆性もよいので不 発残留薬を生ずることは少ないが，発破方法の不適当に 
よるカットオフや，死圧現象によつて不発を生ずること がある。

AN-FO は純白であるため岩石また鉣石中に残留し ている場合発見が極めて容易である。この除去は注水に よつて容易に溶解洗流でき，実験によれば $25 \sim 30 \mathrm{~cm} の$ 残薬を除去するのにわずか13秒位しかかからない。また 万一未発見の残留薬に繰当してす爆発事故を起す危険性 がない。また，多湿の坑内に長時閒放置された AN-FO 爆薬は吸湿潮解して除々纪爆力を失うので極めて安全な 爆薬といえる。

（5）貯蔵 アメリカのManufacturing Chemist Association で作つた規定によると次の通りである。

すなわち，硝灾の許容貯蔵期間はそれぞれの硝安粒の 性質, 堆積の大きさ, 温度, 湿度を考えて決定する。貯 蔵物の高さはその固化の性質によつて定まるが，どんな 時でも天井から $36 \mathrm{in}$ 以上あけねばならぬ。9 $90^{\circ} \mathrm{F}$ 以上の温 度, 高湿度も禁物である。硝安は腐食性があるので卜タ ン, 銅, 鉛, 覀鉛等と接触させてはならぬ。鋼や木は合 成樹脂塗料のような硝安に耐性のあるペンキで 2 回以上 塗ること, 貯蔵容器法清潔で, 硝宽を污染する物質を入 れぬこと, 有機化合物, 可燃性液体, 酸, 塩素酸塩, 過 マンガン酸塩でよごされている場所に貯蔵せぬこと，と くにこれらの活性物質はなんらかの原因で容器が破摃し て両者の混合が起らぬよう硝安の上下に貯蔵してはいけ ない。スチームパイプ,電球, ラヂエータ等の熱源の近く に貯蔵せ妃, 貯蔵場所の床は乾燥していて, 清潔で 硝安のしみこまない不然性のものであること, 溶解した 硝安の流れ出るおそれのあるドレインは火気を除くか, ふさいでおくこと, コンクリート上に直接貯藏する場合 はプラスチックシートのような防水性のもので覆ら必要 がある。喫煙ならびに裸火の使用を篇禁する。火災に対 して十分な備えをしておく。硝安は火薬の貯蔵を認めら れた場所以外では火薬と同時貯蔵をしてはならない。固 化した硝安を碎くためにダイナマイトや，その他の火薬 類を使用してはならない。

\section{むす び}

AN-FO 爆薬について, 最近発表されたものを取りま とめて記したが，AN-FO 爆薬は.まだまだ発展の途上に あり,近着の米誌*によると International Nickel Co. で腎度の高い硝安と燃料油を袋詰にした AN-FO爆弾 と称するものを作つて 2 次発破に用いている。Butte で は燃料油をスプレーでかけてやることで均一性の向上を 考えている。また，カリフホルニヤの一発明家は $60 \%$ $\mathrm{AN}, 40 \% \mathrm{SN}$ の混合物に燃料它加えることにより $\mathrm{AN}$ 一FOより強力なものができることを発見したと述べてい る。わが国でも現場の鉱山! と薬会社が協力して新製品 を開発するとともに，監督官庁も実情をよく崕查の上，

$\mathrm{AN}-\mathrm{FO}$ 発破技術の開発に協力すべきると考える。

\section{引用 文 献}

1) R. J. Grubb: Some Factors Influencing the Explosive Properties of Ammonium Nitrate-Fuel Mixtures.'Proceedings of International Symposium on Mining Research Vol. I

2) 下村弥太郎：AN-FO 爆薬に関する基礎研究，日本釷業会誌，78 巻, 891 号.

3）日本鉱業協会：昭和 37 年度応用研究報告書. 石灭石鉱業協会 : AN-FO の鉱山に䑙汀る発破試験

\section{参考 文 献}

1）山田正幸 : 欧米の火薬業界をみて，工業火薬協会誌，23巻，3号 1962.

2）福山郁生：欧米を旅行して 同上.

3）日野・横川：硝安一燃料一界面活性剤爆蔡，工業火菜協会誌，21 卷, 4 号.

4) 浜野克継：硝油爆蔡 (AN-FO 爆薬) 飞ついて 同上，24巻 I 号

5) How AN-FO Blasting Will Save Money in Your Underground Mine, World Mining Vol. 15, No. 8.

6) K. Hino, M. Yokogawa: Ammonium Nitrate-Fuel-Surfactant Explosives-Their Fundamentals and Performance, Proceedings of International Symposium on Mining Research Vol. I.

7) G. B. Clark, R. F. Bruzewski, J. G. Stites, J. E. Lyon, \& J. J. Yancik : Performance Parameters of Densified MicroPrilled Ammonium Nitrate-Fuel Blasting Agents, Ibid.

8) U. Henning : Blasting with Ammonium Nitrate Fuel Oil Explosives Underground at Boliden, Ibid.

9) R. L. Bullock, L. Bilheimer, \& J. J. Yancik, : Research on the Underground Application of Ammonium NitrateFuel Oil Mixture in Small Diameter Holes, (A Preliminary Report), Ibid.

* Eng'g \& Mining Journal, June 1963.

\section{新}

\section{英 語 の化学論文}

溝口秋子著

われわれが日頃英語の諭交を書く 場合に，しばしば幾多の疑問点にぶ つかりながら，不如意のままに取り 纆めていることが多い。文法正しく 簡潔に，美しく，魅力岁る交章を書 くことは容易なことではない。
ことに，技術系の論交を書く場合 には，文法以外の特殊な表現法を必 要とすることも多く，これらの点に ついて，この本は誠によいアドパイ ザーとなつてくれる。

交法の組みたて，原稿の書き方印
刷まで，と題してそれぞれに多くの 実例をぬげ詳しい説明がなされてい る他に，研究諭文に咽連した手紙や 八ガキ，電報の畫き方安であってこ の上もなく役に立つ。

著者はこの方面の権威者であり, 科学技術情報管理の技術士でぬ る。(三野英彦)

化学の領域・增刊55号 : 昭和38年 6 月, 南江堂 $¥ 800$ 。 